AJST

amca2012.org

\title{
Perceptions on fisherman's insurance: A case study in PPN Prigi, Jawa Timur
}

\author{
Indri Mustikasari ${ }^{1}$ and Rahayu Relawati ${ }^{1}{ }^{*}$ \\ ${ }^{1}$ University of Muhammadiyah Malang, Indonesia \\ *Corresponding author: rahayurelawati@umm.ac.id
}

\section{KEYWORDS \\ Perception \\ Fisherman \\ Insurance \\ Benefit}

SUBMITTED 9 Dec 2020

REVISED 23 Dec 2021

ACCEPTED 21 Jan 2021

\begin{abstract}
Coastal communities commonly depend their income on marine resources with fishing produces as the main income. Their work is quite risky, as fishing is inextricable from work accidents, loss of life, loss of boats and equipment, personal health and safety, and safety of ship crews. This study aims to determine the mechanism of insurance implementation and fishermen's perceptions of the Insurance Assistance Program for Fishermen in Prigi, Trenggalek, Jawa Timur. This present study employed descriptive qualitative. The data was collected through in-depth interviews, observation, and literature study. Results show that the number of insurance participants fluctuated, and even decreased every year during 2018 to 2020. Some of the causing factors were fishermen's lack of interest in the insurance programs due to bad experiences in the past. They reported that the claim submission process was long and complicated when a work accident occurred. Lack of socialization of the insurance program had also made fishermen less familiar.
\end{abstract}

(c) The Author(s) 2021

\section{INTRODUCTION}

The diverse potential of Indonesian seas is influenced by its abundant biological sources. They have economic value that can improve the welfare of Indonesian fishermen. However, national economic development in the fisheries and marine sectors faces various obstacles that hinder efforts to increase fishermen's income and welfare (Ode et al., 2019; W et al., 2019).

Coastal communities are highly supported by marine resources in their economy. They depend on the fish produces, where working as fisherman is risky due to the unstable weather (Rani, 2016; Ulfa, 2018).

Law No. 7/ 2016 Article 30 Paragraph 2 and 3 states the risks faced by fishermen, fish cultivators and salt farmers. The risks include: loss or damage to fishing facilities, fish breeding and salt business; work accidents or loss of life of fishermen, fish breeders and salt farmers; and other types of risk regulated by a Ministerial Regulation. These accidents are commonly due to natural disasters, fish disease outbreaks, the impact of climate change, and/ or pollution (Rani, 2016; Zekri et al., 2008).

Hence, Law No. 7 of 2016 Article 30 states that protection against risks above for fishing and fish farming facilities, and other types of risk, is covered by fishery insurance. Law No. 11 of 2009, article 9 paragraph 2 explains that social security is provided in the form of social welfare insurance and continuous direct assistance, so that people can meet basic needs and live properly. (W et al., 2019),(Purnama, 2015).

Insurance participants have legal protection in making claim payments as regulated in the Consumer Protec- tion Law, Civil Code, Commercial Law, and the Law on Insurance Business. This can warrant the protection for insurance participants, where they do not have further obligations as regulated by policy (Badruzaman, 2019). This present study aims to investigate the perceptions of fishermen toward "Program Bantuan Asuransi bagi Nelayan" (Insurance Assistance Program for Fishermen) in Prigi, Trenggalek, Jawa Timur.

\section{METHOD}

This present study employed descriptive method with a qualitative approach. It aimed to provide an accurate, systematic, and factual picture with regard to certain facts, that was fishermen's perceptions towards the insurance program. This present study employed accidental sampling method. It took place at Pelabuhan Perikanan Nusantara (PPN) (National Fishery Port) in Prigi, Kecamatan Watulimo, Kabupaten Trenggalek Regency. PPN Prigi was chosen because it is mostly inhabited by fishermen. Data collection techniques were in-depth interviews, observations, and literature study.

\section{RESULTS AND DISCUSSION}

PPN Prigi is located in Kecamatan Watulimo, Kabupaten Trenggalek, in the south coast area. Its width is $154.44 \mathrm{~km} 2$ consisting of 12 villages populated by around 66,772 people (Badan Pusat Statistik, 2019). Kecamatan Watulimo is a developed sub-district in fisheries and maritime affairs and agriculture. The residents' livelihoods are mostly as fishermen (5,078 people), fish traders ( 3,053 people), and Others: 


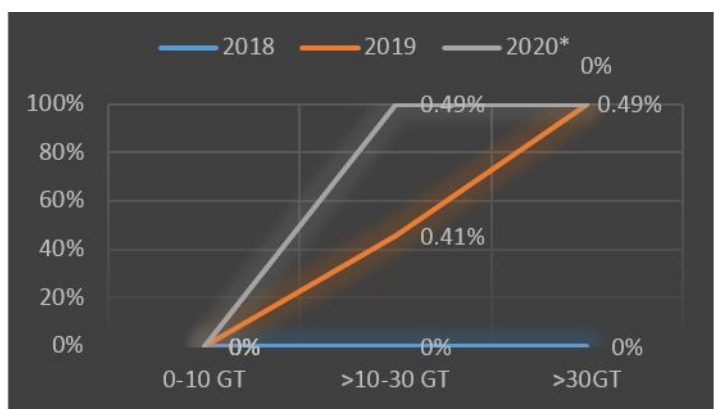

(A)

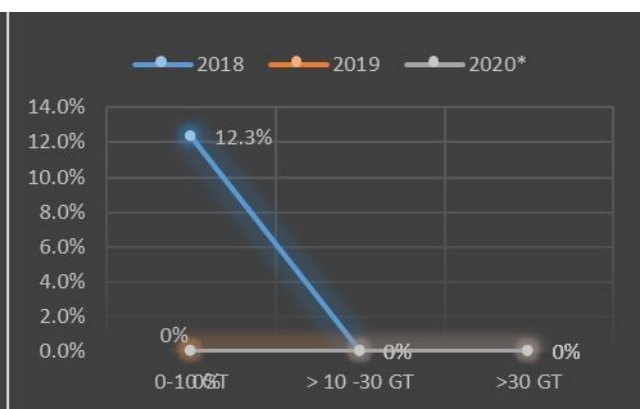

(B)

FIGURE 1. (A) Percentage of BPJS-K participants based on boats' sizes and (B) Percentage of BAPN (Jasindo) participants based on boats' sizes

TABLE 1. Number of participants of BPJS-K dan BAPAN (Jasindo).

\begin{tabular}{|c|c|c|c|c|c|c|}
\hline \multirow[t]{2}{*}{ Year } & \multicolumn{3}{|c|}{ BPJS-K (67) } & \multicolumn{3}{|c|}{ Jasindo (625) } \\
\hline & Boat $0-10 \mathrm{GT}$ & Boat $>10-30 \mathrm{GT}$ & Boat $>30 \mathrm{GT}$ & Boat $0-10 \mathrm{GT}$ & Boat $>10-30$ GT & Boat $>30$ GT \\
\hline 2018 & 0 & 0 & 0 & 625 & 0 & 0 \\
\hline 2019 & 0 & 21 & 25 & 0 & 0 & 0 \\
\hline $2020 *$ & 0 & 21 & 0 & 0 & 0 & 0 \\
\hline
\end{tabular}

*note: valid to 22 Octiber 2020

Source: Primary Data (Processed), 2020.

farmers, civil servants, private businessmen, and tourism workers (1,505 people).

\subsection{Insurance Program}

The implementation of insurance program in PPN Prigi by Kementerian Kelautan dan Perikanan (KKP) (The Ministry of Maritime Affairs and Fisheries) have established partnerships with insurance companies, namely, PT. Asuransi Jasa Indonesia (Jasindo) (Indonesian Insurance Services), which contributes IDR 175,000 per annuum, and Badan Penyelenggara Jaminan Sosial Kesehatan (BPJS) (Board of Health and Welfare Security). BPJS insurance began on May 1, 2019 with a contribution of IDR 16,800 per month.

\subsection{Benefits of Insurance}

Fisherman insurance provided by Jasindo and BPJS give benefits to fishermen. They warrant protection to traditional, small, and labor fishermen against the risk of accidents and loss of life during fishing activities and on land. This insurance also covers senior fishermen (Safitri, 2018).

\subsection{Fishermen's Perceptions}

Obviously, fishermen in PPN Prigi were lacking of interest to join the offered insurance program. It is evident in the data of the numbers of participants of BPJS-K and BAPN (Jasindo).

Figures 1 depict analysis results on the percentage of the number of BPJS-K and BAPN (Jasindo) participants based on boats' sizes in 2018 to 22 October 2020. Figure 1(A) shows an increase in the number of BPJS-K insurance participants. In 2018, there were no BPJS-K insurance participants, from boats sized of 0-10 GT,> $10-30 \mathrm{GT}$, to vessels> 30 GT. However, there was an increase in 2019 of $0.41 \%$ for vessels $>10-30$ GT and $0.49 \%$ for vessels $>30$ GT. In 2020, there was no change for boats sized 0-10 GT. There was an increase in boats sized $>10-30$ GT of about $0.8 \%$ from
TABLE 2. Fishermen's perceptions on fishermen insurance program.

\begin{tabular}{|c|c|c|}
\hline Indicators & Agree & Disagree \\
\hline \multirow[t]{2}{*}{$\begin{array}{l}\text { Reasons to join or } \\
\text { not join insurance } \\
\text { program }\end{array}$} & $\begin{array}{l}\text { To anticipate working } \\
\text { risks }\end{array}$ & $\begin{array}{l}\text { Have joined once and } \\
\text { experienced difficul- } \\
\text { ties in claiming }\end{array}$ \\
\hline & & Unstable income \\
\hline Claim mechanism & Easy & Do not know \\
\hline \multirow[t]{2}{*}{ Premium } & Affordable & Unstable income \\
\hline & $\begin{array}{l}\text { For about IDR } 18,000 \\
\text { per month }\end{array}$ & \\
\hline Benefit & $\begin{array}{l}\text { Understand the bene- } \\
\text { fit of insurance }\end{array}$ & $\begin{array}{l}\text { Understand the bene- } \\
\text { fit of insurance }\end{array}$ \\
\hline \multirow[t]{2}{*}{ Service } & Very satisfactory & Poor service \\
\hline & $\begin{array}{l}\text { Easy register and } \\
\text { claim processes }\end{array}$ & Difficulties to claim \\
\hline
\end{tabular}

$0.41 \%$ in 2019 to $0.49 \%$ in 2020 . Meanwhile, the number of participants decreased to $0 \%$ for for vessels $>30 \mathrm{GT}$ in 2020 .

Figure 1(B) shows that BAPN (Jasindo) participants were only active in 2018 with around $12.3 \%$ or 625 fishermen for vessels measuring 0-10 GT. No fishermen with vessels $>10-$ $30 \mathrm{GT}$ and $>30$ GT participated in the insurance program. This also happened in 2019 and 2020, when fishermen with a vessel size of 0-10 GT in BAPN (Jasindo) experienced a significant decrease, reaching $0 \%$ of participants.

Table 2 summarizes fishermen's perceptions on the insurance program. Those who agreed with the program viewed that the offered insurance was helpful and made them feel protected. On the other hand, those who disagreed were mostly because past experiences related to claiming difficulties when accidents occurred.

Several factors might cause fishermen reject insurance, such as, lack of interest, low socio-economic level, individual character, insurance literacy, available access about the 
insurance, and past experiences. More often, difficulties in claiming insurance when accidents occurred had largely impacted participants' trust. Fishermen often experienced complicated and lengthy process in claiming their rights (Courbage \& Nicolas, 2020).

The lacking of socialization on the benefits of insurance had also affected fishermen's trust. This made a group of fishermen are insurance illiterate, which made them disinterest on the offered program (Ode et al., 2019).

\section{CONCLUSION}

The implementation of the insurance program in PPN Prigi has experienced several obstacles, one of which was the lack of interest of fishermen to join the program. This is evident during 2018 to 2020 period where the number of participants was fluctuating, and declining every year. Some factors caused the fishermen's lack of interest in the insurance program were bad experiences in the claiming process, and lack of socialization about the program offerings.

\section{REFERENCES}

Badan Pusat Statistik. (2019). Kecamatan Watulimo Dalam Angka 2019.

Badruzaman, D. (2019). Perlindungan Hukum Tertanggung Dalam Pembayaran Klaim Asuransi Jiwa. Amwaluna: Jurnal Ekonomi Dan Keuangan Syariah, 3(1), 96-118. https://doi.org/10.29313/amwaluna.v3i1.4217

Courbage, C., \& Nicolas, C. (2020). Trust in insurance: The importance of experiences. Journal of Risk and Insurance, May 2019, 1-29. https://doi.org/10.1111/jori.12324

Ode, L., Syarif, Y., \& Hanafi, I. (2019). Implementation of Fisherman Insurance Assistance Program in South $\mathrm{Bu}-$ ton Regency, Southeast Sulawesi Province. 22(3), 156165.

Purnama, A. (2015). Analisis Perlindungan Jaminan Sosial bagi Pekerja Informal. Jurnal PKS, 14(2), 149-162.

Rani, M. (2016). Insurance protection for Fisherman. Jurnal Selat, 4(1), 1-14.

Safitri, K. A. (2018). The Role of Insurance for Protection against the Risk of Fishing Accidents. KnE Social Sciences, 3(11), 1328. https://doi.org/10.18502/kss.v3i11.2851

Ulfa, M. (2018). Persepsi Masyarakat Nelayan dalam Menghadapi Perubahan Iklim (Ditinjau dalam Aspek Sosial Ekonomi. Jurnal Pendidikan Geografi, 23(1), 41-49. https://doi.org/10.17977/um017v23i12018p041

W, A. R., Alwi, M. J., \& Danial. (2019). Analisis tingkat kebutuhan asuransi nelayan untuk meningkatkan kesejahteran di lokasi Sekaya Maritim Kecamatan Bontoa Kabupaten Maros. Jurnal Ilmiah Agrisains, 20(1), 12-17.

Zekri, S., Daudi Mbaga, M., \& Boughanmi, H. (2008). Fishermen willingness to participate in an insurance program in Oman. Marine Resource Economics, 23(3), 379-391. https://doi.org/10.1086/mre.23.3.42629624 